\title{
Transatlantica
}

Revue d'études américaines. American Studies Journal

1 | 2013

Revisiting the Gilded Age / Littérature et philosophie

\section{Percival Everett International Conference}

Université de Rouen, Maison de l'Université, March 21st and 22nd, 2013

Agathe Berland

\section{(2) OpenEdition}

Journals

Electronic version

URL: https://journals.openedition.org/transatlantica/6305

DOI: $10.4000 /$ transatlantica.6305

ISSN: $1765-2766$

Publisher

Association française d'Etudes Américaines (AFEA)

Electronic reference

Agathe Berland, "Percival Everett International Conference", Transatlantica [Online], 1 | 2013, Online since 16 February 2014, connection on 07 February 2023. URL: http://journals.openedition.org/ transatlantica/6305 ; DOI: https://doi.org/10.4000/transatlantica.6305

This text was automatically generated on 7 February 2023.

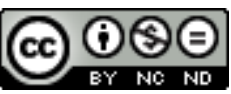

Creative Commons - Attribution-NonCommercial-NoDerivatives 4.0 International - CC BY-NC-ND 4.0 https://creativecommons.org/licenses/by-nc-nd/4.0/ 


\section{Percival Everett International Conference}

Université de Rouen, Maison de l'Université, March 21st and 22nd, 2013

\section{Agathe Berland}

1 This international conference on contemporary American writer Percival Everett, in the presence of the artist, was organized by Anne-Laure Tissut (ERIAC) and focused not only on Everett's literary work but also on his paintings. Some of them were exhibited at the Maison de l'Université, along with a few of his poems translated by Rouen University students. As part of the symposium-the third to be held in France on this prolific author-a meeting with Percival Everett was organized at the L'Armitière bookstore on the occasion of the French publication of his novel Montée aux enfers (Assumption).

\section{Keith Mitchell (University of Massachusetts, Lowell), "Encountering the Face of the Other: Levinasian Ethics in Percival Everett's God's Country"}

2 Keith Mitchell opened the conference with a paper on Percival Everett's 1994 novel God's Country, a parody of American Westerns whose main character Curt Marder seems to embody the immoral project of Manifest Destiny and America's unethical treatment of African-Americans and Native Americans in the 19th century. Keith Mitchell read the novel through the theoretical lens of Emmanuel Levinas's conception of ethics. According to the philosopher, potential responsibility towards one another arises from the encounter with "the face of the other." Keith Mitchell showed how in God's Country Marder proves incapable of experiencing empathy for those around him, his relationships being based not on mutual understanding but on a constant demonstration of power. While the face-to-face encounter with Bubba (the black tracker he hires to help him find his kidnapped wife), in Levinas's "asymmetrical fashion," should lead Marder to see the humanity in him and empathize with this man 
and others who are not like himself, the white cowboy fails to understand or acknowledge the ethical responsibility he has towards him as he never manages to let go of his race-based stereotypes and can only see the other as an alien being.

\section{Françoise Sammarcelli (Université de la Sorbonne, Paris 4), "Vision and Revision in Erasure"}

3 Françoise Sammarcelli's presentation dealt with "vision and revision" in Erasure (2001), a novel in which Percival Everett summons literary and artistic traditions to constantly question the conventions of representation, especially when it comes to black identity. Focusing on the form of the journal, Françoise Sammarcelli showed how it enabled the author to "explore the aesthetics of fragmentation" while challenging the reader's interpretative strategies. Turning the narrator into a ventriloquist, Percival Everett stages unlikely and often very comical dialogues between famous artists and critics, making the reader a partner sometimes bewildered by the extent of intertextual references. He also brings together seemingly random elements and includes lists of words, whose logic escapes the reader, disturbing him and compelling him to constantly change perspectives. The use of blanks and transgressive typography calls attention to the visual quality of the page, introducing distance between words which stand out on paper and become all the more visible in an attempt to make the visual text signify. In the end, Françoise Sammarcelli concluded, all these literary and visual devices aim at drawing the reader's attention to language itself, inviting him to explore language and its possibilities.

\section{Marie-Agnès Gay (Université Lyon 3), " ‘Wanted: Straight Words' in Percival Everett's Novel Wounded"}

In her presentation, Marie-Agnès Gay chose to focus on "the relationship between words and the world" in Wounded (2005), showing the limits of straightforward language in this realistic novel of the West. In spite of the characters' efforts to communicate with words, some things are by nature ungraspable and forthright expression appears inadequate, as it is reductive and often becomes repetitive. She called our attention to the delusion of straightforward discourse, as language is most often unstable. In fact, the privileged way of communication in the novel lies in nonverbal interaction. This unstable nature of language is illustrated in the novel by the repeated use of acronyms whose letters cannot always be associated to a name, and become nothing more than "floating signs" on the page, inviting the reader to pay more attention to the letter itself than to the word behind it. Marie-Agnès Gay thus suggested that in Percival Everett's novel, "straight words" are in fact not wanted since the pleasure of the text lies in the interpretation of indirect signs. Meaning cannot be settled, the meaning of a word shifting from one person to another, depending on what it connotes for them or what they project onto the signifier. Consequently, any attempt at straightforwardness is bound to fail. In fact, as Marie-Agnès Gay demonstrated, the entire novel is "an invitation to play with words on the loose," while being well aware that words will never be captured. 


\section{Clément Ulff (Université de Versailles Saint-Quentin), "Invisible Fathers: Investigating Percival Everett's 'Lower Frequencies' "}

Clément Ulff dedicated his presentation to the characterization of fathers and father figures in three of Percival Everett's novels, drawing a parallel with the unnamed narrator of Ralph Ellison's Invisible Man. In these books, the dead fathers' absent presence is the sign of a problematic bond between father and child. Clément Ulff noted that some themes found in Zulus (1990), such as the suicide of a parental figure, or the investment of objects as spiritual reminders of the dead father, are actually recurrent in Percival Everett's novels. Clément Ulff underlined that in both Assumption (2011) and Erasure (2001) crises arise after the fathers' deaths, from what he calls an "unmanageable moral and cultural patrimony." In Erasure for instance, the problems of communication in the narrator's family come from an unresolved conflict with the father who, by committing suicide, deprived the narrator of the symbolical Oedipal murder he needed to commit to move on with his life. As a conclusion, Clément Ulff invited the audience to look for different patterns in other novels by Percival Everett, where fathers can be either comic or tragic figures but always play a decisive role that could not be fulfilled by anyone else.

\section{Claude Julien (Université de Tours), “Assumption: Ancestry and New Development"}

6 Claude Julien's contribution to the conference first consisted in pointing out the reminiscences from earlier Everett stories like "Wash" (Big Picture, 1996) and "Nice and Warmly Buried" (Damnedifido, 2004) in the first part of Assumption (2011). He examined their function in the light of Jacques Rancière's distinction between "police power" and "politics." According to Claude Julien, by including elements from previous works, the author leads the reader to feel safe in a reassuring world he thinks he already knows and where everything falls back into place. However, in the third part of the book, the reader's familiar, stable world collapses when the main character, a nice, devoted police officer, starts exterminating people, thus disrupting and annihilating police power. In fact, Claude Julien underlined the fact that already in the first and second parts of the novel, "referential ground is never firm under the reader's feet" as the setting lacks substance and some peculiar things can be noticed in the plot. The story, he suggested, could actually be interpreted as a dream from the beginning to the end, a dream gradually turning into a nightmare. Nothing is said about politics, Claude Julien concluded, but in the end the book can be read as an indictment of violence and weapons in America. 


\section{Anthony Stewart (Dalhousie University), "Talking about Race: Exposing the Desire for the Post-racial in Percival Everett's Assumption"}

7 In his paper, Anthony Stewart aimed at showing that issues of race in Percival Everett's Assumption should be approached "along with, rather than instead of, the other large questions encountered in serious fiction." To debunk the notion of the post-racial, Anthony Stewart relied on a review of Assumption in the Wall Street Journal to show how the "desire for the post-racial" influences people's perceptions of society as well as their readings. The reviewer wrote that in the second section of the novel, "race is treated as irrelevant to [Ogden's] character," betraying his own desire for the postracial. Of course racial issues are still very much present, and in Assumption Percival Everett challenges the post-racial. Although Ogden's race is not mentioned directly in the second section of the book, it is implicitly made clear by the attitudes of others around him and his non-whiteness is indirectly underlined several times. The novel's main character is undergoing an identity crisis as he spends his time looking for something or someone which actually turns out to be himself. At the end, the novel remains unresolved and, according to Anthony Stewart, Ogden's final speech, giving no definitive explanation for his behavior, highlights the pointlessness of the desire for the post-racial as it corresponds to a desire to resolve something we cannot thoroughly understand.

\section{Marguerite Déon (Université de Rouen), “Clichés and Cultural Icons in Percival Everett's Fiction"}

8 The second day of the conference started with a presentation by Marguerite Déon who discussed the effects and possible goals of the use of clichés in Percival Everett's fiction and showed that these clichés are often a means to play with the reader's expectations. Focusing on Wounded (2005), she suggested that their function seemed first and foremost to criticize systematic classification of people according to what we think constitutes their identity. In I Am Not Sidney Poitier (2008), Not Sidney's two mentors constantly play on the reader's expectations by regularly uttering sentences that are totally disconnected from the present situation, or even pure gibberish. According to Marguerite Déon, these two highly comical characters' function is to mock encyclopaedism and show how the repeated use of clichés can induce a loss of meaning, but also to make us aware of our propensity to ascribe sense to anything. Taking God's Country (1994) as an example, she then demonstrated how the reader's horizon of expectations is also challenged by the fact that none of Percival Everett's novels ever take the direction one could have expected. "Everett's talent," Marguerite Déon declared, "lies in his ability to disturb the reader as well as to maintain her attention by refusing to give her what she expects," leaving her free to create her own meaning. 


\section{Michel Feith (Université de Nantes), “The Well- Tempered Anachronism, or the $\mathrm{C}(\mathrm{o})$ urse of Empire in Percival Everett's For Her Dark Skin"}

In his article on Percival Everett's revisiting of the myths of Medea and the Argonauts, Michel Feith discussed the use of anachronisms, stating that For Her Dark Skin (1990) is, a re-exploration of myths in the light of American modernity, but that it also sheds light on the contemporary period. The Argonautica is re-interpreted by Percival Everett as a criticism of Western and American culture, a tale of imperialism opposing civilization and barbarians. Michel Feith first underlined the comical aspect of the novel, a travesty of the original works written in colloquial language, debunking the epic hero, criticizing modern democracy and turning Medea into a "desperate housewife." But more importantly, Michel Feith tackled the political dimension of the novel, calling the Argonauts' voyage a "tale of globalization." He showed how Percival Everett's use of anachronism is meant to draw a parallel between the ancient myths and the history of imperialism in America, the expansion of the Greek world mirroring the American conquest of the west and the opposition between civilization and barbarians echoing the American racial discourse towards Native Americans and enslaved Africans. Percival Everett's novel therefore demonstrates how canonical works can perpetuate ideologies and how the ideologies of our times can influence our reading of canonical works.

\section{Isabelle Van Peteghem-Tréard (Classes Préparatoires, Lycée Guist'hau, Nantes), "Jouissance in Damnedifido Stories by Percival Everett"}

10 Isabelle Van Peteghem-Tréard offered a Lacanian reading of two of Percival Everett's short stories, "The Fix" and "The Appropriation of Cultures" (Damnedifido, 2004), taking an interest in the notion of jouissance, both as a symbolical re-appropriation of the usufruct of a property and as pleasure. In "The Fix," she noticed that the plot was literally staged as the reader is given no inner focalization but only dialogue, and the main character, Sherman, is characterized only by the others' comments and reactions. According to Isabelle Van Peteghem-Tréard, "the text seems to display a will to highlight the gap between the written text and the spoken word, which is at the basis of Derrida's theory of differance, thanks to the deconstruction of famous literary tropes and appropriation of the symbolic order." In "The Appropriation of Cultures," the main character disrupts the order of Southern society by challenging the world of signifiers, inverting the signified when he, a black man, expropriates racist whites of their symbols (the song "Dixie," the Confederate flag) only to re-appropriate them, thus reaching jouissance. Isabelle Van Peteghem-Tréard concluded that the fundamental alienation can be erased by literary creation leading to an inversion in the power dynamics. 


\section{Judith Roof (Rice University), “Everett's Eidolon, or The Story of an Eye"}

11 Judith Roof's contribution to the conference was more a performance than a simple paper. She offered the audience a piece of "creative criticism" on Percival Everett's paintings and poetry. Through the figure of the eidolon, "an image, a phantasm, a ghostly remnant, what remains of the seen minus the seeing, what is seen but is not there," she examined the question of perception and representation, thus raising issues of time, space and words, all of which are the subject of Percival Everett's poem "Of Seeing." "The poem," she said, "enacts the paradox of the image by representing the image of the seeing of the image that once seen can never be seen again, except as the memory of a seeing." Judith Roof then discussed the choice of colors, shapes and textures in Percival Everett's paintings, insisting mainly on the recurring motif of the orb, which, she says, can easily be compared to eyes. She noted how these orbs were often decentered, partially escaping the canvas and therefore calling for peripheral vision. Playing with the idea of reflexivity, she suggested that, "if the painting invites some looking, what the viewer sees is the viewer looking at himself looking." Her intervention showed how in Percival Everett's oeuvre, both paintings and poems reflect one another.

\section{Brigitte Félix (Université Paris 8, Saint-Denis), “Of Weeds and Words: Percival Everett's Poetry"}

In the light of Percival Everett's three volumes of poetry (re:f (gesture), 2006, Abstraktion Und Einfühlung, 2008 and Swimming Swimmers Swimming, 2010) Brigitte Félix reflected on the author's use of the genre, showing it was for him "a field for research and experimentation with 'pure form.' " of course Percival Everett's novels are occasions for him to transform a narrative space into a poetic space. However, the author himself explained he saw in poetry "a means of seeking a form of abstraction, or even an abstraction in form that he wishes to achieve in the writing of fiction but says he has not yet found." To illustrate her point, Brigitte Félix selected and commented a few poems from each of the collections. She showed for instance how the visual aspect of a text signifies, with the example of the first section of re:f (gesture), opening with lines borrowed from Percival Everett's Zulus, but written vertically and therefore offering new combinations, new interpretations for the text. In her conclusion, she wondered if Percival Everett's detour with poetry had changed the way the readers approached his fictions, but also whether it had changed his own writing, the latest novels being more and more concerned with language and the possibility and limits of meaning.

\section{Claudine Raynaud (Université Montpellier 3), “Naming, Nonsense and Not Naming in I am Not Sidney Poitier"}

Exploring the implications of the proper name in I am Not Sidney Poitier (2008), Claudine Raynaud examined the function of nonsense in the novel. The many questions and puns around the character's name induce a comic of repetition and eventually verge on the absurd. Not Sidney is deprived of his identity and uniqueness, as he is constantly 
defined in relation to the famous Hollywood actor. Sidney Poitier, Claudine Raynaud reminds us, was "the epitome of the token black actor in a lily-white Hollywood" which allegedly acted towards the resolution of the race problem while actually expressing a lasting reluctance to go beyond the stereotypes of its time. Part of the humor of Percival Everett's novel comes from intertextual references to movies starring Sidney Poitier, the dialogues of which are transcribed in oneiric passages and can be anticipated by the reader. This debunking of racial dynamics is accompanied by an exploration of nonsense and a reflection on the creation of meaning through language, often eclipsing the character's adventures or hindering the progression of the plot. Claudine Raynaud concluded that I am Not Sidney Poitier is a novel flirting with postmodernism and is ultimately about the dissemination of meaning as well as a criticism of the entertainment industry.

\section{Sylvie Bauer (Université Paris-Ouest Nanterre), "Private Turbulent Seas: Painting the Moon in Cutting Lisa by Percival Everett"}

14 Sylvie Bauer dedicated her paper to Percival Everett's 1986 Cutting Lisa, a simple novel by all appearances, but which actually abounds with hidden tensions, and raises the question of the limits of the human. She showed that the very strict routine observed by the main character in his everyday life is in fact an attempt to frame time and control the reality that surrounds him, until the unexpected resurfaces, first in the form of a phone call. When he cannot master his own feelings anymore, he is caught up by time and pain, sent back into a world that escapes the categories he has been using so far. Going west to spend time with his family, the character accepts to loosen his grip on reality, subjecting himself to a de-familiarization which compels him to reconsider his vision of the world as absolute. His obligation to acknowledge the complexity of a reality he had refused to accept leads him to reconsider his definition of the human. As John Livesey realizes that nothing is absolute, and that words eventually fail to express his feelings, he cannot make sense of what is happening to him and has no choice in the end but to let go, to simply take his place in a reality he cannot master. All along her presentation, Sylvie Bauer showed how the paintings of landscapes (and especially of the sea) which punctuate Percival Everett's novel mirror the character's private turbulences.

15 This two-day conference was an opportunity to take stock of recent research on Percival Everett's work. Among the various issues that were addressed were the author's use and subversion of literary traditions and conventions, his attention to visual signification-be it in his novels, poems or paintings-and, above all, his constant will to explore language, both in order to remain innovative and to remind his reader of the volatility of meaning. All the interventions led to very stimulating discussions in which Percival Everett himself took part, along with the researchers and students who attended the event.

Link to the program : http://eriac.net/percival-everett/ 
INDEX

Subjects: Actualité de la recherche

\section{AUTHOR}

AGATHE BERLAND

Rouen University 